\title{
IMMUNOHISTOCHEMICAL DETECTION OF VASA ANTIGEN AND APOPTOSIS-RELATED DNA FRAGMENTATION IN OVARIES OF SHEEP FETUSES PRENATALLY EXPOSED TO VITAMIN D DEFICIENCY
}

\author{
MBEGBU Edmund C. ${ }^{1,2 *}$, OBIDIKE Ikechukwu R. ${ }^{2}$, FOULADI-NASHTA Ali A. ${ }^{1}$ \\ ${ }^{1}$ Comparative Biomedical Sciences, Royal Veterinary College, University of London, UK; \\ ${ }^{2}$ Veterinary Physiology and Pharmacology, University of Nigeria, Nsukka,Nigeria
}

(Received 28 January, Accepted 13 June 2019)

\begin{abstract}
The primordial germ cells (PGCs) in female animals are comprised of diplotene oocytes arrested in the first meiotic prophase. Expression of Vasa is one of the key factors required for subsequent resumption of development and recruitment of PGCs into the growing follicle class. Since vitamin D regulates recruitment of PGCs and developmental competence of ovarian follicles, this study was designed to investigate the expression of Vasa and rate of apoptosis in foetal ovaries prenatally restricted from dietary vitamin D. Nineteen sexually mature Welsh mountain ewes were randomly assigned to vitamin D deficient (VDD) and vitamin D control (VDC) diets from $17 \mathrm{~d}$ before mating, up to $125 \mathrm{~d}$ of gestation, when fetal ovaries were collected and fixed in formalin for immunohistochemistry and TUNEL assay. VDD ovaries had fewer healthy oocytes that could stain positive for Vasa as well as a lower integrated density value for DAB staining intensity. Conversely, TUNNEL staining in VDD animals showed a higher integrated density value and percentage of affected area $(P<0.05)$. The present findings indicate that Vasa expression is decreased, while the rate of apoptosis increased in VDD fetal ovaries, and this may adversely affect resumption of growth and development of PGCs reserve.
\end{abstract}

Key words: apoptosis, ovary, sheep, Vasa, vitamin D deficiency

\section{INTRODUCTION}

The primordial germ cells (PGCs) in female animals are comprised of cells containing diplotene oocytes arrested in the first meiotic prophase [1]. Expression of Vasa is one of the key factors required for subsequent resumption of development and recruitment of PGCs into the growing follicle class [2]. By convention the reserve is established when all individual oocytes are enclosed by granulosa cells of mesodermal origin. This

*Corresponding author: e-mail: edmund.mbegbu@unn.edu.ng 
commonly occurs prior to or around birth, according to species [3]. Oogenesis begins with the formation of primordial germ cells during the early stages of embryonic development [4]. Proliferating PGC's migrate from the extra-embryonic mesoderm, through the hindgut, to eventually colonize the bipotential gonadal ridge [4].

After a period of sex differentiation, oogonia increase in number by incomplete mitotic division that results in clusters of germ cell nests connected via intercellular bridges [5]. These structures, termed ovigeous cords, form the major component of the ovarian cortex [6]. Meiosis I begins when germ cells closest to the medulla cease mitosis and enter meiotic prophase I (MPI). Oogonia entering MPI are now termed 'oocytes', and progress through the leptotene, zygotene and pachytene stages of MPI to become arrested at the diplotene stage [5].

The key events in the morphogenesis of the ovine fetal ovary include colonization by PGCs, the interaction of PGCs with somatic cells, formation and disappearance of ovigeous cords and the establishment of a population of definitive primordial follicles. Although species differences in the timing of specific events are found, the overall chronology of developmental events that culminate in the formation of primordial follicles appears to be similar in all mammals. By 125 days gestational age, sheep fetal ovary contains the main classes of follicles by this stage of development [6-8].

Vasa (also known as Ddx4) is an ATP-dependent RNA helicase, which is a fundamental member of the DEAD-box protein family which plays a peculiar role in the process of primordial germ cell specification and embryonic posterior patterning, hence it is regarded as a reliable germ cell marker [2]. Currently, expression of Vasa has been characterized in diverse vertebrates and even insects, and it is highly conserved among various organisms [9]. Apart from germline development, Vasa is also expressed in multipotent somatic cell types, indicating that it could have a potential function in regenerative and proliferative activities of most body organs [10-12].

Vitamin $\mathrm{D}$ is a steroid hormone, synthesized mainly by the skin on exposure to ultraviolet light. Low percentage of vitamin D (up to 20\%) is provided by the diet [13]. The active form of vitamin D, 1,25-dihydroxyvitamin D3 mediates its action through vitamin D receptor (VDR); which is a member of the steroid/ thyroid nuclear hormone receptor superfamily [14]. Nuclear localization of 1,25-dihydroxyvitamin D3 and VDR has been reported in most female reproductive organs like the endometrium, myometrium, ovary, mammary gland, cervix, and placenta [15], suggesting a potential role of vitamin $\mathrm{D}$ in female reproductive physiology. For instance, it has been reported that consumption of ergocalciferol normalized the reproductive cycles and resulted in pregnancy in patients with fertility problems [16]. Vitamin D regulates recruitment of PGCs and developmental competence of ovarian follicles. Vitamin D deficiency for instance is known to increase the secretion of follicle stimulating hormone (FSH), leading to excessive recruitment of primordial follicles [17].

In the ovary, Vasa is expressed by the cytoplasm of oogonia and oocytes of developing follicles $[18,19]$. The expression of Vasa directly reflects germ cells integrity and 
their competence to resume meiotic cell division for progression of normal follicle recruitment and development [2], leading to decreased germ cell survival and altered viability of the ovarian germ cells line [5]. Since there are increasing numbers of reports linking vitamin D deficiency to female infertility [20-22], this study was designed to investigate the impact of vitamin D deficiency on Vasa expression and apoptosis at the early stage of establishment of germ cells line in sheep foetuses.

\section{MATERIALS AND METHODS}

\section{Experimental design}

Nineteen mature first parity Welsh Mountain ewes with body condition score of 2.5-3.0 had their oestrous cycle synchronized by withdrawal of vaginal sponges impregnated with medoxyprogesterone acetate. The ewes were randomly assigned to one of two nutritional treatment groups, vitamin D control (VDC) and experimental vitamin D deficient (VDD) groups. Vitamin D control group comprised of 9 ewes fed with complete pelleted diet containing 2,000 IU $/ \mathrm{kg}$ body weight of vitamin D (P316, Charwood Milling). On the other hand, VDD group was made up of 10 ewes were fed with a customized brand of $\mathrm{P} 316$ prepared with $0 \mathrm{IU} / \mathrm{kg}$ body weight of vitamin D. Feed and water were available ad libitum from 17 days prior to natural mating, and throughout the entire gestation period, with animals excluded from direct UVB exposure from sunlight. The study protocol was approved by UK government Home Office and RVC local ethics committee (RVC Study Number: CU3-NVITD1-12-13).

\section{Tissue Collection and Processing}

At 125 days gestational age (dGA), singleton-bearing ewes were humanely sacrificed and their fetuses harvested from the uterine horns. Blood samples were also collected from both the ewes and fetuses for determination of serum $25(\mathrm{OH}) \mathrm{D}$ concentrations. A total of 5 female fetuses (serum total 25(OH)D $>37 \mathrm{nmol} / \mathrm{L}$ ) were obtained from VDC dams, and 4 female fetuses (serum total $25(\mathrm{OH}) \mathrm{D}<37 \mathrm{nmol} / \mathrm{L}$ ) were collected from VDD dams, respectively. Whole fetal and ovarian weights of the fetuses were obtained. After determining organ weights, the right ovary of each fetus was snapfrozen in liquid nitrogen and stored at $-80^{\circ} \mathrm{C}$ pending mRNA extraction, and the left ovary formalin fixed and embedded in paraffin blocks by standard methods. Serial sections of $5 \mu \mathrm{m}$ thickness were obtained using microtome (Leica Microsystems, Nussloch, Germany). The sections were applied onto HCL-treated, Poly-L-Lysinecoated glass slides and left to dry overnight in an incubator set at $37^{\circ} \mathrm{C}$.

\section{Measurement of Serum Vitamin D}

The concentration of $25 \mathrm{OHD}_{2}$ and $25 \mathrm{OHD}_{3}$ (when combined is termed total circulating $25 \mathrm{OHD}\left(25 \mathrm{OHD}_{\text {TOтАL }}\right.$ ) was determined in foetal lithium heparin plasma samples by high performance liquid chromatography tandem mass spectrometry 
(LC-MS/ MS) [23]. 25OHD 2 and $25 \mathrm{OHD}_{3}$ were extracted by isotopic dilution protein precipitation from $100 \mu \mathrm{l}$ plasma. Following the addition of zinc sulphate, an acetonitrile solution containing hexa-deuterated $25 \mathrm{OHD}_{3}-[26,26,26,27,27,27,-$ $2 \mathrm{H} 6]$ (2H6-25OHD 3 ) was added to the samples as internal recovery standard. After centrifugation, the supernatant was injected into Sunfire C18 $3.5 \mu \mathrm{m} \mathrm{2.1x50} \mathrm{mm}$ chromatography columns (Waters, $\mathrm{UK}$ ), and $25 \mathrm{OHD}_{3}$ and $25 \mathrm{OHD}_{2}$ were separated (flow rate of $0.4 \mathrm{ml} / \mathrm{min}$ ). Potential interfering compounds were removed by gradient elution using initially $88 \%$ methanol:water which was gradually increased to $100 \%$ methanol over run time of 4.5 min. Mass detection was performed by Ultima $\mathrm{Pt}$ LC-MS/ MS system (Micromass, UK) [24]. Identification and quantification is based on multiple reaction monitoring of each analyte specific ion transitions. Quantifier transitions used were $413>271\left(25 \mathrm{OHD}_{2}\right), 401>383\left(25 \mathrm{OHD}_{3}\right)$, and $407>107$ (2H6$\left.25 \mathrm{OHD}_{3}\right)$. Qualifer ion transitions $413>395\left(25 \mathrm{OHD}_{2}\right), 401>258\left(25 \mathrm{OHD}_{3}\right)$ were used to monitor each analyte, with the requirement that the quantifier/qualifier ion ratio must be within $\pm 20 \%$ for confirming the presence in samples. Assay sensitivity was determined by the lower limit of quantification: $25 \mathrm{OHD}_{3}=2.5 \mathrm{nmol} / \mathrm{l}$ and $25 \mathrm{OHD}_{2}$ $=2.5 \mathrm{nmol} / \mathrm{l}$. Assay imprecision was assessed for both $25 \mathrm{OHD}_{2}$ and $25 \mathrm{OHD}_{3}$ over linear working range from $0-300 \mathrm{nmol} / 1$.

Extraction efficiency (extraction of vitamin D from matrix) was assessed by determining the amount of $25 \mathrm{OHD}_{3} / \mathrm{D}_{2}$ recovered from the amount added $(50,100$ and $500 \mathrm{nmol} / \mathrm{l}$ ) to plasma prior to extraction taking into account the endogenous concentration of the plasma sample.

\section{Immunohistochemistry (IHC) for Vasa}

In order to establish the presence of Vasa antigens, staining for Vasa was performed using optimized immunohistochemical localization procedure contained in Vectastain Elite ABC kit (Vector Laboratories, Peterborough, UK). Briefly, $5 \mu \mathrm{m}$ thick fixed tissue sections were deparaffinized in Histoclear (Fisher Scientific, Loughborough, UK) and rehydrated in descending grades of ethanol. Antigen unmasking was performed by microwave pretreatment for 5 minutes high power and 7 minutes medium power in $0.01 \mathrm{M}$ sodium citrate buffer ( $\mathrm{pH}$ 6.0), then allowed to cool down at room temperature. Sections were immersed in 3\% hydrogen peroxide (Sigma-Aldrich, Dorset, UK) in methanol (Sigma-Aldrich, Dorset, UK) for 20 minutes to quench endogenous peroxidase activity. Slides were blocked in 10\% normal goat serum (Vectastain Elite ABC kit, Vector Laboratories, Peterborough, UK) with $4 \%$ bovine serum albumin (BSA) in PBS for 1 hour in a humidified chamber. The sections were incubated with primary antibody at $4^{\circ} \mathrm{C}$ overnight with Avidin (1:100) and Biotin (1:250) blocking reagents. The primary antibody used was monoclonal mouse anti-human Vasa (Abcam, Cambridge, UK) Cat. No. ab209710; applied in the ratio of 1:300. The negative controls were treated with PBS1XT. 
The sections were washed in PBS and incubated with 1:200 goat anti-mouse immunoglobulin G (secondary antibody) diluted in PBS for 60 minutes; washed in PBS and treated with Avidin-Biotin complex solution for 30 minutes at room temperature. The sections were then washed and developed with 3\% (v/v) 3,3-diaminobenzidine (DAB) chromogen in peroxidase substrate diluent for 3 minutes in a dark chamber. The $\mathrm{DAB}$ staining was stopped by washing the section with distilled water, counterstained using 40\% (v/v) Gill's Haematoxylin (Park Scientific, Northampton, UK) for 20 seconds, dehydrated in ascending grades of ethanol for 1 minute each followed by immersing twice in Histoclear for 2 minutes each. Finally, tissues were mounted with coverslips using DPX (distyrene, plasticizer and xylene) mountant (BDH Laboratory, England, UK). Images were collected using a DM4000Bright field upright microscope (Leica Microsystems, Milton Keynes, UK), and DC500 color camera (Leica Microsystems, Milton Keynes, UK). Both the microscope and the camera were connected to the desktop computer installed with Leica Application Suite software version 2.8.1 for windows. The objective used was 5x HC PL FLUOTAR PH1 (NA=0.3).

\section{TUNEL Assay for Apoptosis}

Terminal deoxynucleotidyl transferase (TdT) dUTP Nick-End Labeling (TUNEL) assay for apoptosis was performed according to standard method [25]. The formalin fixed ovary sections were de-waxed in histoclear II (National Diagnostics, Hessle Hull, England, UK) and rehydrated in descending grades of alcohol and PBS containing 1\% BSA for 10 minutes. Antigen retrieval was done with $0.1 \mathrm{M}$ sodium citrate $(\mathrm{pH}=6.0)$ for 5 minutes in high power followed by 7 minutes in medium power microwave (Sanyo Electric Co. Ltd, UK). The tissues were permeablized with 1\% Triton X-100 in PBS for 5 minutes and endogenous peroxidase blocked with 3\% hydrogen peroxide in methanol. Incubation with TUNEL reagent (In Situ Cell Death Detection Kit, Fluorescein, Roche Life Sciences, UK) was done for 1 hour in a humidified chamber at $37^{\circ} \mathrm{C}$ according to the manufacturer's instruction. Briefly, a 1:10 solution of the TUNEL enzyme (reagent 1) and buffer (reagent 2) was prepared for the rest of the assay. Following TUNEL staining, the sections were washed quickly in PBS before being stained with $10 \mu \mathrm{g} / \mu \mathrm{l}$ solution of Hoescht 33422 (Thermofisher Scientific, UK) for 5 minutes at room temperature in an opaque humidified chamber. Hoescht is a DNA binding dye and enables visualization of oocyte nuclei which appear blue under a fluorescent microscope. The tissue sections were then mounted with a small droplet of anti-fading Vectashield mounting medium (without DAPI) and observed using a Leica fluorescent microscope. Apoptotic cells contain damaged DNA which binds to the TUNEL reagent and appear green under the green fluorescent light. The intensity of the staining was quantified using the color deconvolution tool of ImageJ software.

\section{Statistical Analysis}

The computer software, IBM statistical package for social sciences (SPSS) statistics version 23.0 for windows (IBM Corp, Armonk, NY, USA) was used for the statistical 
analyses. Data obtained were statistically analyzed using independent student's t-test. The means were separated using Duncan's New Multiple Range Test and differences in the means less than probability values of $0.05(\mathrm{p}<0.05)$ were considered significant. The results were presented in pictures, graphs and tables as means \pm standard errors of the means.

\section{RESULTS}

\section{Effect of maternal vitamin $D$ exclusion on fetal plasma vitamin $\mathrm{D}$ concentrations}

The result showed that exclusion of vitamin $\mathrm{D}$ from the diet of sheep during periconceptional and gestational periods significantly $(p<0.05)$ reduced the plasma concentrations of vitamin D3 and vitamin D2+D3 in the female fetuses. The fetal offspring from vitamin $\mathrm{D}$ deficient dams had vitamin D3 serum concentration of $12.93 \pm 2.21 \mathrm{nmol} / \mathrm{L}$ against $25.24 \pm 4.15 \mathrm{nmol} / \mathrm{L}$ recorded in the control group. The values of the sum total of vitamin $\mathrm{D} 2+\mathrm{D} 3$ for the vitamin deficient and control groups are $33.08 \pm 3.11 \mathrm{nmol} / \mathrm{L}$ and $58.48 \pm 8.49 \mathrm{nmol} / \mathrm{L}$ respectively. The treatment did not affect the serum level of vitamin D2 (Fig. 1).

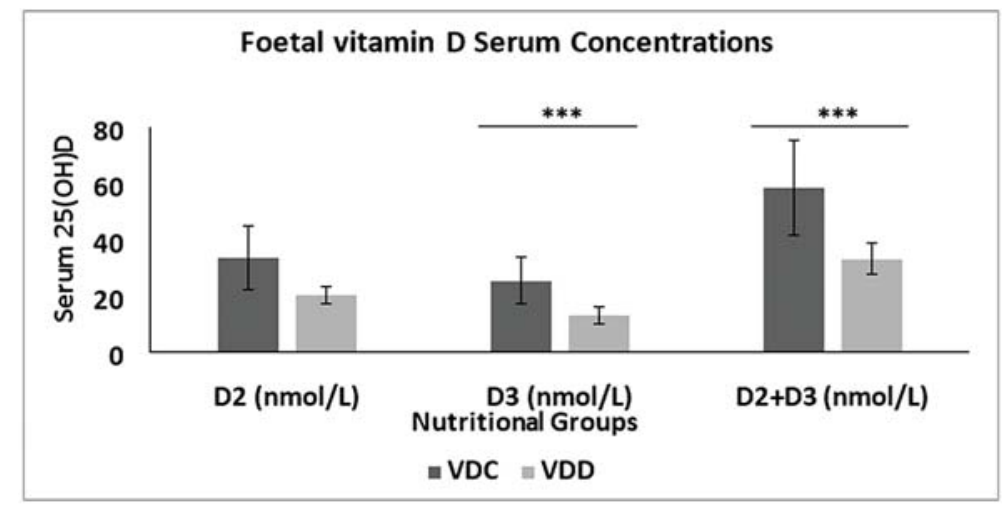

Figure 1. Serum levels of vitamin D2 and D3 in foetuses following periconceptional and gestational exposure of female sheep to vitamin $\mathrm{D}$ deficient diet. Induction of vitamin $\mathrm{D}$ deficiency caused a significant reduction in vitamin D3 and combined vitamin D2+D3 levels

\section{IHC for Vasa in fetal ovaries following maternal vitamin D exclusion}

Immunoperoxidase immunohistochemistry detected Vasa in the oocyte cytoplasm of the ovarian follicles in both VDC (Fig. 2) and VDD (Fig. 3). There were fewer healthy oocytes among the depleted population of oocytes that could stain positive for Vasa in VDD fetal ovaries while the VDC ovaries had many primordial follicles and greater number of the follicles that stained positive for Vasa. 


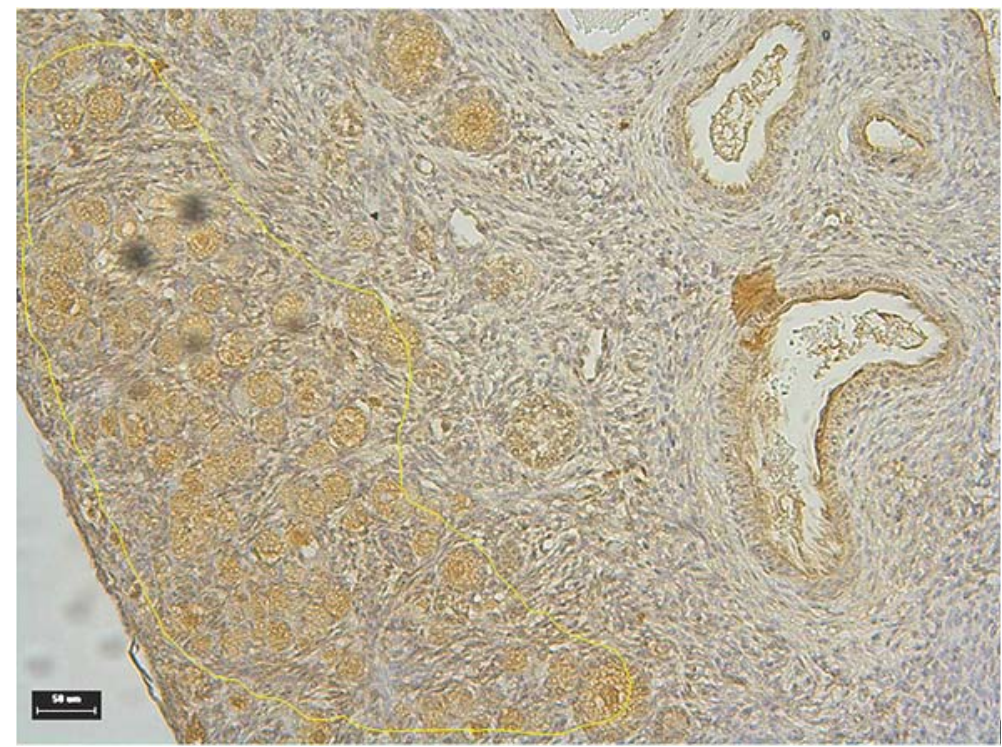

Figure 2. Photomicrograph of the Immunoperoxidase immunohistochemistry for Vasa in ovary from vitamin D control (VDC) group. Note the presence of many primordial follicles and greater population of healthy oocytes that picked the DAB stain. Magnification $=\mathrm{X} 100$. Scale bar $=50 \mu \mathrm{m}$.

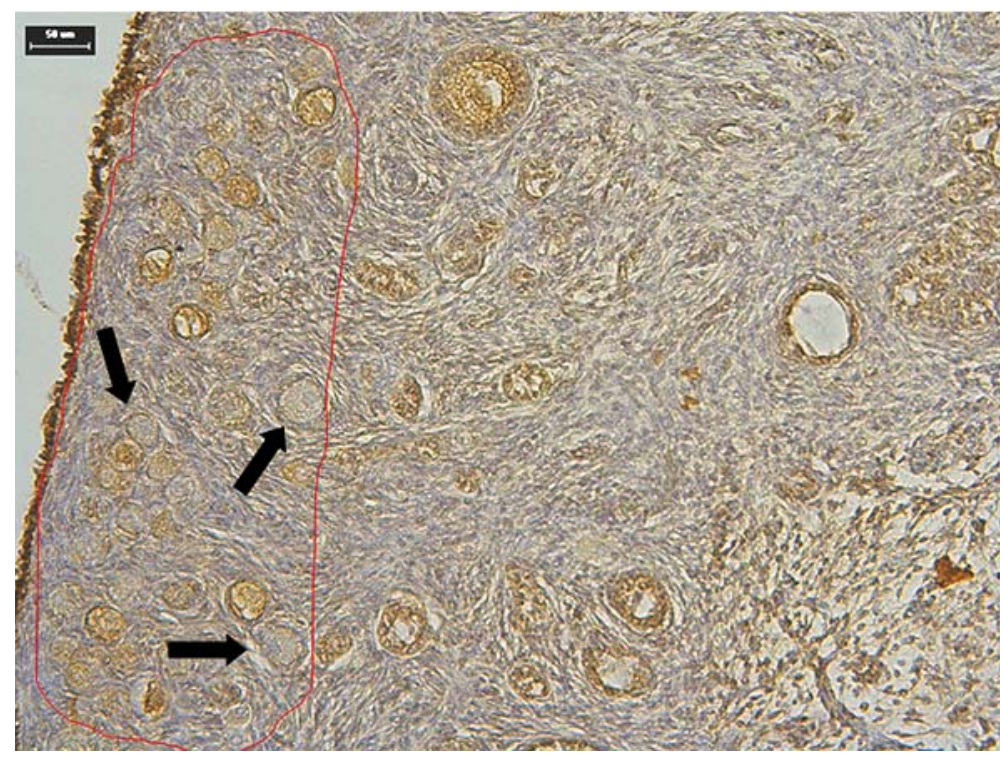

Figure 3. Photomicrograph of the Immunoperoxidase immunohistochemistry for Vasa in ovary from vitamin D deficient (VDD) group. Note the depleted primordial follicles and fewer number of healthy oocytes that picked the DAB stain. Unhealthy primordial follicles could not pick DAB stain for Vasa (black arrows). Scale bar $=50 \mu \mathrm{m}$. 


\section{Effect of maternal vitamin D exclusion on rate of apoptosis in fetal ovaries}

To determine whether the observed decline in follicular counts was due to increase in the rate of apoptosis, we performed TUNEL assay for apoptosis. The result showed that sections of fetal ovaries from the vitamin $\mathrm{D}$ deficient group detected more DNA fragments from cells undergoing apoptosis compared to ovary sections from the control group (Fig. 4), indicating that maternal vitamin D deficiency could have induced the loss of oocyte pool in the fetal ovaries. Using the color deconvolution tool of ImageJ software, the integrated density of the staining, as well as the ovarian areas containing apoptotic cells were quantified. The TUNEL staining density and percentage of affected area were higher $(\mathrm{p}<0.05)$ in vitamin $\mathrm{D}$ deficient group compared to the control group (Table 1), confirming that more cells were undergoing programmed cell death in the vitamin $\mathrm{D}$ deficient fetal ovaries.
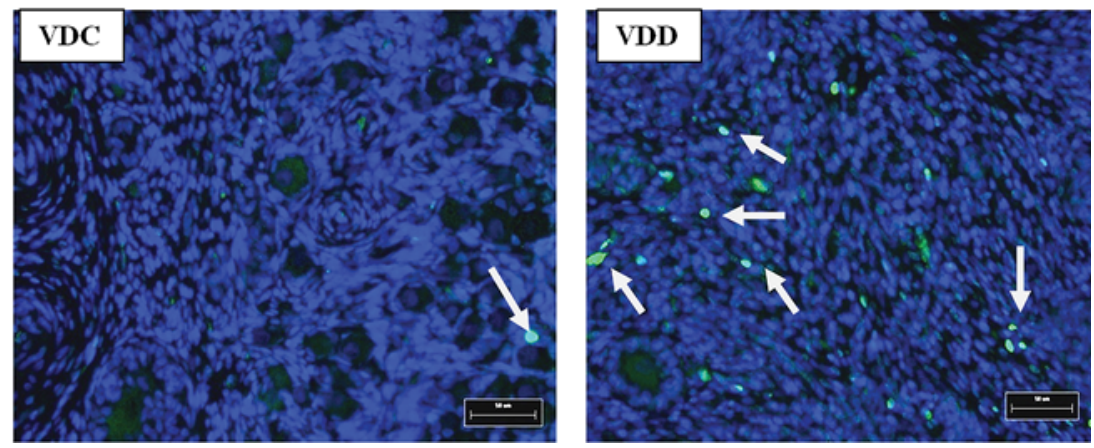

Figure 4. TUNEL assay for apoptotic cells in the ovaries. Bright green colored dots represent disintegrating apoptotic cells (white arrow). Magnification $=$ X100. Vitamin D deficient ovaries had more TUNEL-labeled cells undergoing apoptosis

Table 1. Integrated density and percentage of affected areas in TUNEL labeled fetal ovarian tissues following periconceptional and gestational exposure of female sheep to vitamin D deficient diet. Vitamin D deficient ovaries had significantly higher TUNEL staining density and percentage of affected area

\begin{tabular}{lccc}
\hline GROUP & Area (pixels) & $\begin{array}{c}\text { Integrated Density } \\
\text { (pixels) }\end{array}$ & \% Affected Area \\
\hline VDC & $78984.90 \pm 14071.33$ & $2310.75 \pm 55.29$ & $4.07 \pm 1.64$ \\
VDD & $51333.25 \pm 18576.95$ & $5946.00 \pm 104.46^{* *}$ & $12.22 \pm 3.12^{* *}$ \\
\hline
\end{tabular}

Means with asterisk $(* *)$ in a column are significantly different $(\mathrm{p}<0.05)$

\section{DISCUSSION}

Exclusion of vitamin D from the maternal diet during periconceptional and gestational periods significantly reduced the serum concentrations of vitamin D2 and vitamin D3 in their female offspring. Owing to the fact that the sheep were confined in an environment devoid of direct exposure to UVB rays, the vitamin D status of the 
experimental groups was largely dependent on the diet. Through placental transfer, developing fetuses depend on their mother for supply of vitamin D [26]. With the vitamin $\mathrm{D}$ deficient diet fed to the dams, the quantity of $25(\mathrm{OH}) \mathrm{D}$ available for absorption through the enterocytes brush-border membrane (through passive diffusion and cholesterol transporters) could be limited [27].

In this study, the plasma level of vitamin D2 did not differ between the VDC and VDD fetuses. However, the concentration of vitamin D3 in VDD fetuses was found to be significantly lower when compared to the VDC fetuses. The lower level of total $25(\mathrm{OH}) \mathrm{D}$ in the VDD fetuses is invariably due to the corresponding decrease in the vitamin D3 serum concentration. Indeed, serum $25(\mathrm{OH}) \mathrm{D}$ concentrations is generally considered the best biomarker of total biologically available vitamin $\mathrm{D}$, reflecting nutritional status [28]. The VDC fetuses had total 25(OH)D above $37 \mathrm{nmol} / \mathrm{L}$, while the VDD foetuses had 25(OH)D below $37 \mathrm{nmol} / \mathrm{L}$. This falls within the range of the minimum vitamin $\mathrm{D}$ level in lambs proposed by National Research Council which is $148 \mathrm{IU} / \mathrm{kg}(51.75 \mathrm{nmol} / \mathrm{L})[29]$.

Healthy ovarian follicles are primarily indispensable for optimal folliculogenesis and fertility in female domestic animals. The quality of the primordial follicles recruited invariably determines the developmental outcomes of the successive follicular types [2]. Vasa is one important germ cell biomarker that signifies the health status of primordial follicles. In this study, the immunoperoxidase immunohistochemistry for Vasa conducted showed its expression in the cytoplasm of oogonia and oocytes of recruited and developing follicles [18,19]. The integrity of the germ cells determines the intensity of the staining for Vasa. This reflects the competence to resume meiotic cell division for progression of normal follicle recruitment and development [2]. Expression of cells that stained positive for Vasa significantly reduced in the VDD fetal ovaries, implying a possible delay in meiotic entry and progression from oogonia to oocyte during fetal development which may be linked to decreased germ cell survival [5]. Immunoperoxidase immunohistochemistry for Vasa revealed that there are fewer healthy oocytes among the depleted population of oocytes that could stain positive for Vasa in VDD group. The poor fertility outcomes prevalent in vitamin D deficient individuals could therefore be due to recruitment of primordial follicles with inherent inability for growth and development. The VDC ovaries had many primordial follicles and greater number of the follicles stained positive for Vasa. Vitamin D deficiency therefore has the tendency to alter the viability of the ovarian germ cells line. It could as well imply that vitamin D deficiency can adversely affect primordial follicles recruitment and subsequent developmental competence. As previously documented, Vasa is massively expressed in the primordial follicles compared to other follicular types [30]. This could be due to the extreme need for proliferation in this class of follicles.

Apoptosis is a programmed cell death responsible for up to $99 \%$ loss of initial ovarian follicle pool, hence necessary for maintenance of ovarian homeostasis [31]. Furthermore, whether apoptosis occurs in the germ cells or supporting follicular 
compartments might depend on the stage of development [31]. For example, during early fetal life, apoptosis can be identified at the level of the germ cell itself, whereas later in development, when the large majority of folliculogenesis has already occurred, it is more common to detect apoptosis in the granulosa cells of follicles [31]. In this study, apoptosis was detected more frequently in the granulosa and theca cell layers possibly due to the fact that the fetuses were harvested at $125 \mathrm{~d}$ gestation, when development of the oocytes were already arrested at the diplotene stage of meiosis and ovarian reserve established. Terminal deoxynucleotidyl transferase (TdT) dUTP Nick-End Labeling (TUNEL) assay detects apoptotic cells at their terminal stage when there is extensive DNA degradation. The TdT enzyme binds to the blunt ends of double-stranded DNA breaks using a fluorescent dye system [32]. TUNEL assay for detection of apoptotic cells in the sections of VDD fetal ovaries showed that more granulosa cells were undergoing apoptosis compared to VDC ovaries. TUNEL staining density and percentage of affected area increased in VDD fetal ovaries compared to VDC fetal ovaries. This suggests DNA damage in the degenerating granulosa cells surrounding the developing follicles [33]. The granulosa cells are the key to the maintenance of the integrity of the oocytes [34]. This implies that death of these cells will consequently warrant atresia of the developing follicles in which they are found. Follicle stimulating hormone is needed to sustain the viability of the granulosa cells, but vitamin D deficiency causes AMH-induced inhibition of FSH in the developing follicles, leading to cellular degeneration and detectable late stage DNA fragments [35]. The detection of DNA damage in the oocyte is usually delayed and seldom measurable above background, hence the oocytes did not pick the TUNEL staining [33].

In conclusion, the present findings indicate that vitamin D deficiency could negatively affect recruitment of primordial follicles and developmental competence of the PGCs reserve, and the increased rate of programmed cell death could be sequel to the decreased Vasa expression. The combined impact of these observations could result in lowered fertility and early depletion of the primordial germ reserve.

\section{Acknowledgements}

This work was financially supported by Tertiary Education Trust Fund (TETFund) AST\&D University of Nigeria, Nsukka, with reference number UN/VC/T/19/N.2. I am also grateful to the Department of Comparative Biomedical Sciences, Royal Veterinary College, University of London for their technical support during my parttime research in United Kingdom.

\section{Authors' contributions}

MEC participated in the design of the experiment, carried out the molecular laboratory/statistical analysis and drafted the initial manuscript. OIR supervised the design of the experiment and participated in the development of the manuscript. 
FAA designed the work, participated in the molecular laboratory analysis and drafting of the manuscript. All authors read and approved the final manuscript.

\section{Declaration of conflicting interests}

The author(s) declared no potential conflicts of interest with respect to the research, authorship, and/or publication of this article.

\section{REFERENCES}

1. Dutta S, Burks DM, Pepling ME: Arrest at the diplotene stage of meiotic prophase $\mathrm{I}$ is delayed by progesterone but is not required for primordial follicle formation in mice. Reproductive biology and Endocrinology 2016, 14(1): 82.

2. Song K, Ma W, Huang C, Ding J, Cui D, Zhang M: Expression Pattern of Mouse Vasa Homologue (MVH) in the Ovaries of C57BL/6 Female Mice. Medical science monitor. International Medical Journal of Experimental and Clinical Research 2016, 22: 2656-2663.

3. Kerr JB, Myers M, Anderson RA: The dynamics of the primordial follicle reserve. Reproduction 2013, 146: 205-215.

4. Nikolic A, Volarevic V, Armstrong L, Lako M, Stojkovic M: Primordial Germ Cells: Current Knowledge and Perspectives. Stem Cells International 2016, 1741072.

5. Hartshorne GM, Lyrakou S, Hamoda H, Oloto E, Ghafari F: Oogenesis and cell death in human prenatal ovaries: what are the criteria for oocyte selection? Molecular Human Reproduction 2009, 15(12): 805-819.

6. Juengel JL, Sawyer HR, Smith PR, Quirke LD, Heath DA, Lun S, Wakefield SJ, McNatty KP: Origins of follicular cells and ontogeny of steroidogenesis in ovine fetal ovaries. Molecular and Cellular Endocrinology 2002, 191(1): 1-10.

7. Sawyer HT, Smith P, Heath DA, Juengel JL, Wakefield SJ, McNatty KP: Formation of ovarian follicles during fetal development in sheep. Biology of Reproduction 2002, 66: 1134-1150.

8. Bellingham M, Amezaga MR, Mandon-Pepin B, Speers CJB, Kyle CE, Evans NP, Sharpe RM, Cotinot C, Rhind SM, Fowler PA: Exposure to chemical cocktails before or after conception - The effect of timing on ovarian development. Molecular and Cellular Endocrinology 2013, 376(1-2): 156-172.

9. Rosner A, Moiseeva E, Rinkevich Y, Lapidot Z, Rinkevich B: Vasa and the germ line lineage in a colonial urochordate. Developmental Biology 2009, 331: 113-128.

10. Gustafson EA, Wessel GM: Vasa genes: Emerging roles in the germ line and in multipotent cells. Bioessays 2010, 32: 626-637.

11. Rouhana L, Shibata N, Nishimura O, Agata K: Different requirements for conserved post-transcriptional regulators in planarian regeneration and stem cell maintenance. Developmental Biology 2010, 341: 429-443.

12. Wagner DE, Ho JJ, Reddien PW: Genetic regulators of a pluripotent adult stem cell system in planarians identified by RNAi and clonal analysis. Cell Stem Cell 2012, 10: 299-311.

13. Bouillon R, Carmeliet G, Daci E, Segaert S, Verstuyf A: Vitamin D metabolism and action. Osteoporosis International 1998, 8(1): 13-19. 
14. Johnson LE, DeLuca HF: Vitamin D receptor null mutant mice fed high levels of calcium are fertile. Journal of Nutrition 2001, 131(6): 1787-1791.

15. Vienonen A, Miettinen S, Blauer M, Martikainen PM, Tomas E, Heinonen PK., Ylikomi T: Expression of nuclear receptors and cofactors in human endometrium and myometrium. Journal of the Society for Gynecologic Investigation 2004, 11: 104-112.

16. Lerchbaum E, Obermayer-Pietsch B: Vitamin D and fertility: a systematic review. European Journal of Endocrinology 2012, 166(5): 765-778.

17. Merhi ZO, Seifer DB, Weedon J, Adeyemi O, Holman S, Anastos K, Golub ET, Young M, Karim R, Greenblatt R, Minkoff H: Circulating Vitamin D Correlates with Serum AntiMullerian Hormone Levels in Late Reproductive-Aged Women: Women's Interagency HIV Study. Fertility and Sterility 2012, 98(1): 228-234.

18. Albamonte MS, Willis MA, Albamonte MI, Jensen F, Espinosa MB, Vitullo AD: The developing human ovary: immunohistochemical analysis of germ-cell-specific Vasa protein, BCL-2/BAX expression balance and apoptosis. Human Reproduction 2008, 23(8): 1895-1901.

19. Xu H, Lim M, Dwarakanath M, Hong Y: Vasa Identifies Germ Cells and Critical Stages of Oogenesis in the Asian Seabass. International Journal of Biological Sciences 2014, 10(2): 225-235.

20. Ozkan S, Jindal S, Greenseid K, Shu J, Zeitlian G, Hickmon C, Pal, L: Replete vitamin D stores predict reproductive success following IVF. Fertility and Sterility 2010, 94(4): 13141319.

21. Anagnostis P, Karras S, Goulis DG: Vitamin D in human reproduction: A narrative review. International Journal of Clinical Practice 2013, 67(3): 225-235.

22. Garcia-Velasco JA, Iglesias C, Fabris A: Vitamin D and in vitro fertilization outcome. American Journal of Obstetrics and Gynecology 2014, 212(3): 412-413.

23. Snellman G, Melhus H, Gedeborg R, Byberg L, Berglund L, Wernroth L, Michaëlsson $\mathrm{K}$ : Determining vitamin D status: a comparison between commercially available assays. PLoSONE 2010, 5(7): e11555.

24. Owens DJ, Webber D, Impey SG, Tang J, Donovan TF, Fraser WD, Morton JP, Close GL: Vitamin D supplementation does not improve human skeletal muscle contractile properties in insufficient young males. European Journal of Applied Physiology 2014, 114(6): 13091320.

25. Fouladi-Nashta AA, Alberio R, Kafi M, Nicholas B, Campbell KH, Webb R: Differential staining combined with TUNEL labelling to detect apoptosis in preimplantation bovine embryos. Reproduction Biomed Online 2005, 10(4): 497-502.

26. Torrens C, Fayyaz M, Mercken L, Cooper C, Harvey NC, Oreffo RO, Calder PC, Hanson MA, Poore KR, Green LR: Vitamin D deficient diet in pregnancy alters isolated femoral vasodilatation in the late gestation fetal sheep. Proceedings of the Physiological Society 2015, 34: PC130.

27. Silva MC, Furlanetto TW: Intestinal absorption of vitamin D: a systematic review. Nutrition Reviews 2018, 76(1): 60-76.

28. Pilz S, März W, Cashman KD, Kiely ME, Whiting SJ, Holick MF, Grant WB, Pludowski P, Hiligsmann M, Trummer C, Schwetz V, Lerchbaum E, Pandis M, Tomaschitz A, Grübler MR, Gaksch M, Verheyen N, Hollis BW, Rejnmark L, Karras SN, Hahn A, BischoffFerrari HA, Reichrath J, Jorde R, Elmadfa I, Vieth R, Scragg R, Calvo MS, van Schoor NM, Bouillon R, Lips P, Itkonen ST, Martineau AR, Lamberg-Allardt C, Zittermann A: Rationale 
and Plan for Vitamin D Food Fortification: A Review and Guidance Paper. Frontiers in Endocrinology 2018, 9: 373.

29. NRC 2007: Nutrient Requirements of Small Ruminants: Sheep, Goats, Cervids, and New World Camelids. Washington DC: The National Academies Press.

30. Bonnet A, Bevilacqua C, Benne F, Bodin L, Cotinot C, Liaubet L, Sancristobal M, Sarry J, Terenina E, Martin P, Tosser-Klopp G, Mandon-Pepin B: Transcriptome profiling of sheep granulosa cells and oocytes during early follicular development obtained by laser capture microdissection. BMC genomics 2011, 12: 417.

31. Santos SS, Ferreira MA, Pinto JA, Sampaio RV, Carvalho AC, Silva TV, Costa NN, Cordeiro MS, Miranda MS, Ribeiro HF, Ohashi OM: Characterization of folliculogenesis and the occurrence of apoptosis in the development of the bovine fetal ovary, Theriogenology 2013, 79(2): 344-350.

32. Kyrylkova K, Kyryachenko S, Leid M, Kioussi C: Detection of apoptosis by TUNEL assay. Methods in Molecular Biology 2012, 887: 41-47.

33. Roti Roti EC, Leisman SK, Abbott DH, Salih SM: Acute Doxorubicin Insult in the Mouse Ovary is Cell- and Follicle-Type Dependent. PLoS ONE 2012, 7(8): e42293.

34. BhardwajJK, Saraf P: Morphological Attributes of Granulosa Cells Perpetuating Functional integrity of an Ovarian follicles. Journal of Advanced Microscopy Research 2017, 12(2): 92-96.

35. Shen M, Jiang Y, Guan Z, Cao Y, Sun S, Liu H: FSH protects mouse granulosa cells from oxidative damage by repressing mitophagy. Scientific Reports2016, 6: 38090.

\section{IMUNOHISTOHEMIJSKA DETEKCIJA VASA ANTIGENA I DNK FRAGMENTACIJE PRILIKOM APOPTOZE U JAJNICIMA FETUSA OVACA PRENATALNO IZLOŽENIH DEFICITU VITAMINA D}

MBEGBU Edmund C., OBIDIKE Ikechukwu R., FOULADI-NASHTA Ali A.

Primordijalne matične ćelije (PGC) kod ženki sastoje se od diplotenih oocita zaustavljenih u prvoj profazi mejoze. Ekspresija Vasa je jedan od ključnih faktora neophodnih za razvoj i mobilizaciju PGC u folikulima u razvoju. Obzirom da vitamin D reguliše mobilizaciju PGC i razvoj folikula jajnika, ova studija ima za cilj da ispita ekspresiju Vasa antigena i stopu apoptoze u fetalnim jajnicima prenatalno uskraćenih u vitaminu D. Devetnest polno zrelih Welsh ovaca su nasumično raspodeljene u vitamin $\mathrm{D}$ deficitarnu grupu (VDD) i kontrolnu (VDC) grupu 17 dana pre pripusta, sve do 1250 g dana gestacije kada su uklonjeni fetalni jajnici koji su nakon toga fiksirani u formalinu za imunocitohemijsko i TUNEL ispitivanje. VDD jajnici su imali manje zdravih oocita koji su bili pozitivni na Vasa antigen, kao i niže vrednosti gustine DAB bojenja. TUNNEL bojenje kod VDD životinja je pokazalo više vrednosti integrisane gustine i zahvaćene površine $(\mathrm{P}<0,05)$. Navedeni nalazi ukazuju da je ekspresija Vasa smanjena, a stopa apoptoze povećana kod VDD fetalnih jajnika. Sve ovo može da negativno utiče na rast i razvoj PGC. 